\title{
Article/Artigo
}

\section{Clinical, demographic and epidemiological characteristics of patients with hepatitis $B$ followed at a university hospital in southeastern Brazil: predominance of HBeAg negative cases}

\author{
Características clínicas, demográficas e epidemiológicas dos pacientes com hepatite B em seguimento \\ em hospital universitário no sudeste do Brasil: predominância de casos $\mathrm{HBeAg}$ negativos
}

\begin{abstract}
Silvana Gama Florencio Chachá ${ }^{1}$, Sandro da Costa Ferreira ${ }^{2}$, Tarciana Vieira Costa ${ }^{3}$, Luiz Carlos de Almeida Filho ${ }^{3}$, Márcia Guimarães Villanova ${ }^{3}$, Fernanda Fernandes Souza ${ }^{3}$, Andreza Correa Teixeira ${ }^{3}$, José Fernando de Castro Figueiredo $\dagger$, Sérgio Zucoloto ${ }^{4}$, Leandra Naira Ramalho ${ }^{4}$, Afonso Dinis da Costa Passos ${ }^{5}$ and Ana de Lourdes Candolo Martinelli ${ }^{2}$
\end{abstract}

\begin{abstract}
Introduction: Hepatitis B is common in Brazil, although there are regional differences regarding the degree of endemicity, the most frequent forms of transmission and the presence of different evolutive stages of chronic disease. The present study aimed to determine the clinical, demographic and epidemiological characteristics of patients chronically infected with hepatitis B virus (HBV) residing in the Ribeirão Preto region, southeastern Brazil. Methods: A total of 529 medical records of individuals with HBV monoinfection were reviewed. Results: More than $60 \%$ of the subjects were males, with a mean age of 38 years-old. The HBeAg-negative serological pattern was verified in $84.4 \%$ of the patients, among whom the risk of vertical/intrafamily transmission was $43.2 \%(p=0.02)$. The consumption of alcohol in amounts exceeding $20 \mathrm{~g}$ a day was observed in $21.3 \%$ of the subjects and was more frequent among men (33\%) $(\mathrm{p}<0.001)$. Among patients with cirrhosis, $54.1 \%$ were alcohol abusers $(\mathrm{p}=0.04)$, all of them males. The presence of cirrhosis was more frequent in the HBeAg-positive group (24.4\%) than in the HBeAgnegative group $(10.2 \%)(p<0.001)$. Conclusions: High proportions of HBV-infected subjects with an HBeAg-negative pattern were observed, with a higher risk of vertical/intrafamily transmission. Alcohol abuse was associated with male subjects and with cirrhosis of the liver in this group. A tendency toward an increase in the number of HBeAg-negative cases was observed over time.

Keywords: Hepatitis B. Epidemiology. Transmission. Hepatitis B E antigens.
\end{abstract}

\begin{abstract}
RESUMO
Introdução: No Brasil, a hepatite B é comum. No entanto, há diferenças regionais no que diz respeito ao grau de endemicidade, as formas de transmissão mais encontradas e a presença dos diferentes estágios evolutivos da doença crônica. O objetivo deste trabalho foi o de conhecer características clínicas, demográficas e epidemiológicas de pacientes cronicamente infectados pelo vírus da hepatite B (HBV), residentes na região de Ribeirão Preto, no sudeste do Brasil. Métodos: Foi realizada a análise retrospectiva de 529 prontuários de indivíduos com monoinfecção pelo HBV. Resultados: Mais de $60 \%$ eram masculinos, a média de idade foi de 38 anos. O padrão sorológico HBeAg negativo foi encontrado em $84,4 \%$ dos pacientes, entre os quais o risco para transmissão vertical/intrafamiliar foi de $43,2 \%(p=0,02)$. Verificou-se uso de álcool em quantidades maiores que $20 \mathrm{~g}$ ao dia em $21,3 \%$ dos indivíduos, sendo mais frequente entre os homens $(33 \%)(\mathrm{p}<0,001)$. Entre os pacientes com cirrose, $54,1 \%$ faziam uso abusivo de bebidas alcoólicas $(\mathrm{p}=0,04)$, sendo todos estes do gênero masculino. A presença de cirrose foi maior no grupo HBeAg positivo $(24,4 \%)$ que no grupo HBeAg negativo $(10,2 \%)$ ( $p<0,001)$. Conclusões: Observaram-se elevadas proporções de indivíduos com infecção pelo $\mathrm{HBV}$ com padrão sorológico $\mathrm{HBe} \mathrm{Ag}$ negativo, entre os quais houve maior risco para a transmissão vertical/intrafamiliar. $\mathrm{O}$ uso abusivo de álcool esteve associado a indivíduos do sexo masculino e, neste grupo, à cirrose hepática. Observou-se tendência ao aumento no número de casos HBeAg negativo ao longo do tempo.

Palavras-chaves: Hepatite B. Epidemiologia. Transmissão. Antígenos E da Hepatite B.
\end{abstract}

1. Department of Medicine, Federal University of São Carlos, São Carlos, SP, Brazil. 2. Division of Gastroenterology, Department of Internal Medicine, Faculty of Medicine of Ribeirão Preto, University of São Paulo, Ribeirão Preto, SP, Brazil. 3. University Hospital, Faculty of Medicine of Ribeirão Preto, University of São Paulo, Ribeirão Preto, SP, Brazil. 4.Department of Pathology, Faculty of Medicine of Ribeirão Preto, University of São Paulo, Ribeirão Preto, SP, Brazil. 5. Department of Social Medicine, Faculty of Medicine of Ribeirão Preto, University of São Paulo, Ribeirão Preto, SP, Brazil.

†In memorium.

Address to: Dra. Silvana Gama Florencio Chachá. Dept ${ }^{\circ}$ Medicina/UFSCAR. Rod Washington Luiz Km 235, 13565-905 São Carlos, SP.

Phone: 55 16 3351-8340

e-mail: silvanachacha@ufscar.br

Received in 01/07/2010

Accepted in 06/10/2010

\section{INTRODUCTION}

Hepatitis B is one of the most common infectious diseases worldwide. More than 2 billion people have had contact with hepatitis B virus (HBV) and about 350 million people have the chronic form of infection ${ }^{1-3}$. The importance of chronic infection resides in the risk of developing serious forms of hepatic disease, such as cirrhosis, liver failure and hepatocellular carcinoma $(\mathrm{HCC})^{1-3}$. Although most individuals do not develop complications during their lifetime, 15 to $40 \%$ of persons with chronic HBV infection will present sequelae related to infection, with a 10 to $20 \%$ estimate of progression to cirrhosis every 5 years $^{1-3}$. The relative risk of developing HCC among chronically HBV-infected individuals ranges from 5.6 to 103.0 and the age of the individual at the time of infection is important in determining this risk $\mathrm{k}^{1-4}$.

The incidence of hepatitis $B$, the patterns of transmission and the frequency of different stages in the natural history of chronic HBV infection varies widely throughout the world in different population subgroups $^{1,3}$. In Brazil, studies conducted in capitals and major cities show data consistent with low or intermediate levels of endemicity ${ }^{5-10}$. The Amazon region, some areas in the State of Espirito Santo and the western areas of the States of Parana and Santa Catarina are distinguished from other Brazilian regions by the high prevalence of $\mathrm{HBV}$ infection ${ }^{7,11,12}$. In areas of low prevalence, transmission occurs more frequently among adolescents and adults, especially through sexual relations. In contrast, in areas of intermediate and high prevalence, data show higher rates of vertical and intrafamilial transmissions $\mathrm{s}^{7,8,13-15}$. The frequency of the different phases involved in the natural history of chronic HBV infection has been poorly investigated in Brazil. Few studies include frequency analysis of $\mathrm{HBeAg}$ negative and $\mathrm{HBeAg}$ positive forms of the chronic infection ${ }^{16,17}$. 
The objective of the present study was to determine the clinical, demographic and epidemiological characteristics of chronically HBVinfected patients followed in Ribeirão Preto, a city in the interior of the State of São Paulo.

\section{METHODS}

This work was conducted as a descriptive epidemiological study. The medical records of HBV-infected patients attended at the Hepatitis B Outpatient Clinic of the University Hospital, Faculty of Medicine of Ribeirão Preto, University of São Paulo (HCFMRP-USP) from June 2004 to June 2008 were reviewed. Of these, $529 \mathrm{HBV}$-infected patients were included in the study. Inclusion criteria were $\mathrm{HBsAg}$ positive patients at diagnosis, with anti-HCV and anti-HIV negative markers.

Data regarding patient identification, referral source, alcohol consumption and risk factors related to HBV transmission were collected. Abusive alcohol consumption was considered to be present when more than $20 \mathrm{~g}$ a day were consumed for more than 10 years.

Anti-HBc IgG-positive antibodies in the mother and/or at least one sibling were considered to indicate possible vertical/intrafamilial transmission of HBV. Risky sexual contact was defined as more than three sex partners per year, a report of a sexually transmissible disease, sexual contact with an individual known to be infected with HBV, or in the case of men who had sex with men. Percutaneous exposure to potentially contaminated material was considered to have occurred when the patient reported the execution of tattoos, piercings or acupuncture.

The following determinations were performed: measurement of alanine aminotransferase (ALT), quantitative DNA values of B virus (HBV DNA), presence of $\mathrm{HBs} A g$ and $\mathrm{HBeAg}$ antigens and of anti-HBcAg IgG and IgM, anti-HBsAg and anti-HBeAg antibodies in serum and, when available, a liver biopsy. On the basis of these data, the patients were classified into different evolutive stages of the disease: acute hepatitis, immune tolerance phase, chronic HBeAgpositive hepatitis, inactive HBV or HBeAg-negative chronic hepatitis, according to the criteria of the American Association for the Study of Liver Diseases (AASLD) ${ }^{18}$. Cirrhosis was diagnosed according to the histopathological findings of the liver biopsy. When a biopsy was not available, the diagnosis was made on the basis of clinical (ascites, hepatic encephalopathy), biochemical (prothrombin time, serum bilirubin and albumin), ultrasonographic (nodules in the liver parenchyma), and endoscopic (signs of portal hypertension) parameters. HCC was diagnosed by imaging exams (ultrasonography + computed tomography and/or magnetic resonance), by the determination of serum alpha-fetoprotein and, when available, by histopathological analysis of the tumor.

The information collected was stored in a data bank using the Excel 2003 software (Microsoft Office). Data are expressed by means of descriptive statistical analysis or were analyzed by the Student $t$ test, Chi square test and Fisher exact test using the SPSS version 17.0 software. The level of significance was set at $\mathrm{p}<0.05$ in all analyses.

\section{Ethical considerations}

The study was approved by the Research Ethics Committee of the Clinics Hospital of the Faculty of Medicine of Ribeirão Preto, University of São Paulo, Ribeirão Preto (HC-FMRP-USP) (protocol n 14339/2006).

\section{RESULTS}

Of the 529 patients included in the study, 320 (60.5\%) were males. Age at the beginning of follow-up ranged from 12 to 79 yearsold, with a mean of 38 years-old. The age of $84 \%$ of the patients ranged from 20 to 59 years-old. Mean age was similar for men (38.0 years-old) and women ( 37.8 years-old) $(p=0.85)$.

Of the total number of patients included in the study, 208 (39.3\%) were referred by clinicians, 181 (34.2\%) were referred by the Ribeirão Preto Blood Center and 103 (19.5\%) were included after family screening. Information regarding the source of referral was not available in 37 (7\%) medical records.

Two hundred and ninety-six (56\%) patients reported that they had not consumed alcohol in any phase of life. The absence of alcohol consumption was more common among women than among men; i.e., $88.5 \%$ and $34.4 \%$, respectively $(\mathrm{p}<0.001)$. Data regarding the amount of alcohol consumed by the men and women included in the study are listed in Table 1.

TABLE 1 - Consumption of alcoholic beverages by HBV-infected patients.

\begin{tabular}{|c|c|c|c|c|c|}
\hline \multirow[b]{3}{*}{ Quantity of alcohol consumed per day in grams } & \multicolumn{4}{|c|}{ Sex } & \multirow[b]{3}{*}{$\mathrm{p}$} \\
\hline & \multicolumn{2}{|c|}{ male } & \multicolumn{2}{|c|}{ female } & \\
\hline & $\mathrm{n}$ & $\%$ & $\mathrm{n}$ & $\%$ & \\
\hline$\overline{\text { Absent }}$ & 110 & 34.4 & 185 & 88.5 & $<0.001$ \\
\hline Less than 20 & 79 & 24.8 & 13 & 6.3 & $<0.001$ \\
\hline 20 to 40 & 43 & 13.4 & 4 & 1.9 & $<0.001$ \\
\hline More than 40 & 63 & 19.6 & 3 & 1.4 & $<0.001$ \\
\hline Unknown & & 25.0 & 7.8 & 4.0 & 1.9 \\
\hline Total & 320 & 100.0 & 209 & 100.0 & \\
\hline
\end{tabular}

Eight patients (1.5\%) presented symptomatic acute hepatitis on the occasion of the first visit. One of them developed acute hepatic insufficiency and died, another developed chronification of the infection and six progressed to spontaneous cure. The remaining $521(98.5 \%)$ patients included in the study presented chronic HBV infection since the beginning of follow-up.

Of the 521 patients with chronic HBV infection, 440 (84.5\%) had the HBeAg-negative and anti-HBeAg-positive serological pattern. Of these, 238 (54.1\%) presented active chronic hepatitis and 202 (45.9\%) were inactive HBV carriers. Eighty-one (15.5\%) individuals had the HBeAg-positive and anti-HBeAg-negative serological pattern. Fifty-nine (72.8\%) of the latter presented active chronic hepatitis and the remaining $22(27.2 \%)$ were in the immune tolerance phase. Of the 521 patients with chronic HBV infection, 297 (57\%) presented active chronic hepatitis.

Analysis of the HBeAg and anti-HBeAg serological pattern at the beginning of patient follow-up revealed a tendency toward an increased number of $\mathrm{HBeAg}$-negative and anti-HBeAg-positive individuals over time; i.e., between January 1992 and December 2007 (Figure 1). Data for 2008 were excluded from this analysis, because the collection did not include the second half of the year in question.

The clinical, demographic and epidemiological characteristics of patients with chronic $\mathrm{HBV}$ infection with $\mathrm{HBeAg}$-positive and HBeAg-negative patterns (age, sex, risk factor, presence of cirrhosis and HCC) are presented in Table 2. 


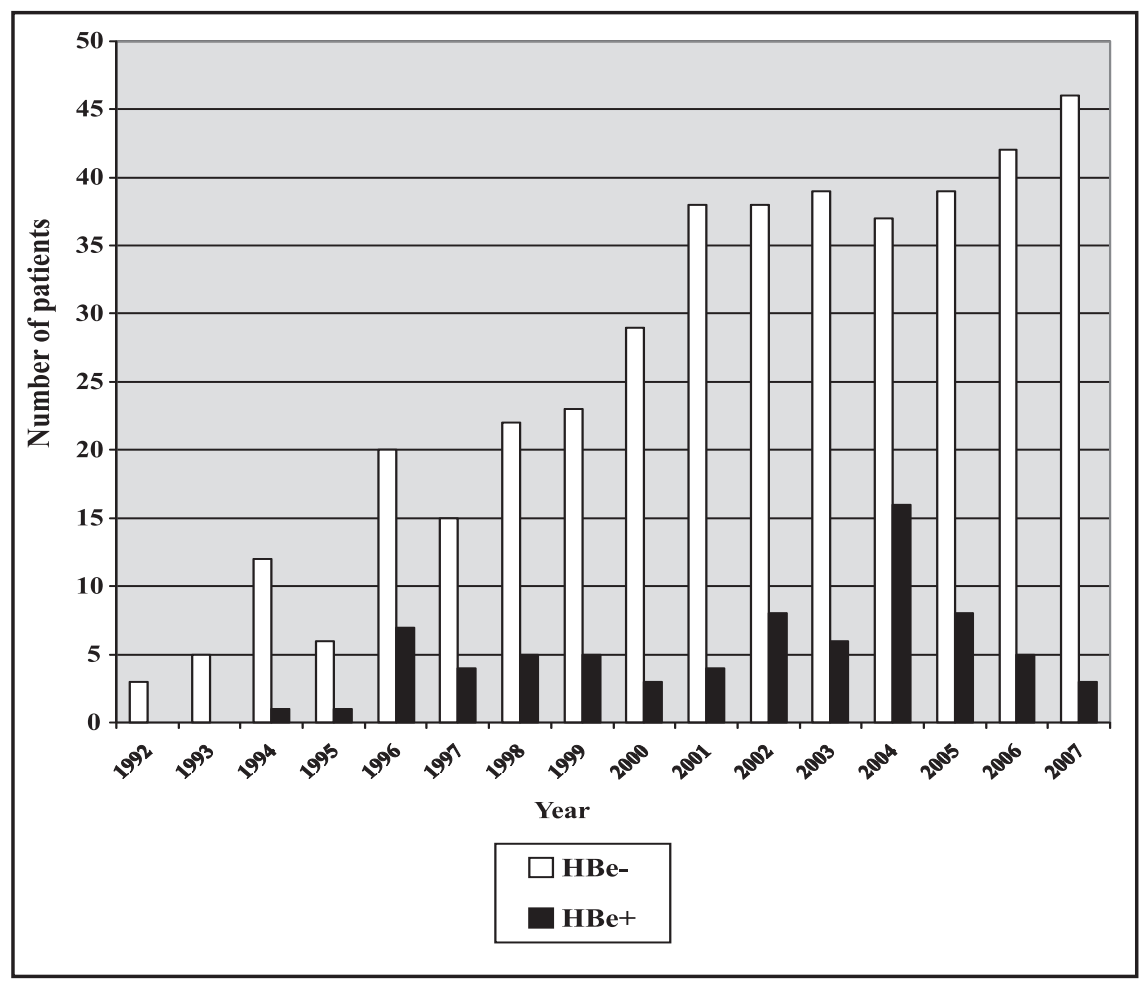

FIGURE 1 - Distribution of the number of new cases of patients with hepatitis B attended at HC-FMRPUSP between 1992 and 2007, according to the serological pattern of the HBe antigen.

TABLE 2 - Clinical, demographic and epidemiological characteristics of patients with chronic hepatitis $B$ infection according to the serological pattern of the HBe antigen.

\begin{tabular}{|c|c|c|c|c|c|}
\hline & \multicolumn{4}{|c|}{$\mathrm{HBeAg}$ positive $\mathrm{HBeAg}$ negative } & \multirow[b]{3}{*}{$\mathrm{p}$} \\
\hline & & & & 440 & \\
\hline \multirow[t]{2}{*}{ Mean age (years) } & \multicolumn{2}{|c|}{36.7} & \multicolumn{2}{|c|}{38.4} & \\
\hline & $\mathrm{n}$ & $\%$ & $\mathrm{n}$ & $\%$ & 0.40 \\
\hline Male sex & 59 & 72.8 & 256 & 64 & 0.02 \\
\hline \multicolumn{6}{|l|}{ Possible mode of transmission } \\
\hline vertical/intrafamilial & 24 & 29.3 & 190 & 43.2 & 0.02 \\
\hline sexual & 27 & 33.0 & 94 & 21.4 & 0.02 \\
\hline transfusion of blood products & 13 & 16.0 & 48 & 10.9 & 0.19 \\
\hline percutaneous & 8 & 9.8 & 10 & 2.3 & $<0.001$ \\
\hline risky injections & - & - & 12 & 2.7 & 0.23 \\
\hline hemodialysis & 2 & 2.4 & 7 & 1.6 & 0.64 \\
\hline health professionals & 1 & 1.2 & 16 & 3.6 & 0.49 \\
\hline unidentified & 21 & 26.5 & 138 & 31.4 & 0.95 \\
\hline more than one factor & 15 & 18.5 & 66 & 15.0 & 0.42 \\
\hline Presence of cirrhosis & 20 & 24.4 & 45 & 10.2 & $<0.001$ \\
\hline Presence of $\mathrm{HCC}^{*}$ & 3 & 3.6 & 13 & 2.9 & 0.72 \\
\hline
\end{tabular}

Table 3 lists the clinical, demographic and epidemiological data of $\mathrm{HBeAg}$-positive and $\mathrm{HBeAg}$-negative patients with active chronic hepatitis. Patients in the immune tolerance phase and patients with inactive $\mathrm{HBV}$ infection were not included in this table. Data were analyzed statistically in a univariate manner.

Of the total of 521 patients with chronic HBV infection, $65(12.5 \%)$ received a diagnosis of cirrhosis during the study period. The mean age of these cirrhotic patients was greater than that of the group of non-cirrhotic patients (48.7 versus 36.5 years-old)
TABLE 3 - Clinical, demographic and epidemiological characteristics of patients with active chronic hepatitis $B$, according to the serological pattern of the HBe antigen.

\begin{tabular}{|c|c|c|c|c|c|}
\hline & \multicolumn{4}{|c|}{$\mathrm{HBeAg}$ positive $\mathrm{HBeAg}$ negative } & \multirow[b]{3}{*}{$\mathrm{p}$} \\
\hline & \multicolumn{2}{|c|}{$\mathrm{n}=59$} & \multicolumn{2}{|c|}{$\mathrm{n}=238$} & \\
\hline \multirow[t]{2}{*}{ Mean age (years) } & \multicolumn{2}{|c|}{37.4} & \multicolumn{2}{|c|}{38.8} & \\
\hline & $\mathrm{n}$ & $\%$ & $\mathrm{n}$ & $\%$ & 0.48 \\
\hline Male sex & 44 & 74.5 & 146 & 61.1 & 0.06 \\
\hline \multicolumn{6}{|l|}{ Possible mode of transmission } \\
\hline vertical/intrafamilial & 19 & 32.2 & 99 & 41.6 & 0.18 \\
\hline sexual & 19 & 32.2 & 48 & 20.1 & 0.04 \\
\hline transfusion of blood products & 12 & 20.3 & 32 & 13.4 & 0.18 \\
\hline percutaneous & 6 & 10.1 & 5 & 2.1 & 0.01 \\
\hline risky injections & - & - & 6 & 2.5 & 0.60 \\
\hline hemodialysis & 1 & 1.7 & 7 & 2.9 & 1.00 \\
\hline health professionals & 1 & 1.7 & 7 & 2.9 & 1.00 \\
\hline unidentified & 12 & 20.3 & 74 & 31.1 & 0.10 \\
\hline more than one factor & 12 & 20.3 & 31 & 13.0 & 0.15 \\
\hline Alcohol intake ( $>20 \mathrm{~g} /$ day $)$ & 20 & 33.9 & 51 & 21.4 & 0.04 \\
\hline Presence of cirrhosis & 20 & 33.9 & 39 & 16.3 & $<0.001$ \\
\hline Presence of $\mathrm{HCC}^{*}$ & 3 & 13.6 & 9 & 3.7 & 0.71 \\
\hline
\end{tabular}

( $\mathrm{p}<0.001)$. Seventy-eight percent were men $(51 / 65)$, demonstrating an association between male sex and this form of hepatic disease $(\mathrm{p}=0.001)$. Information concerning alcohol consumption was available for 59 cirrhotic patients. In the male group, 26 (54.1\%) out of 48 cirrhotic patients consumed more than $20 \mathrm{~g}$ of alcohol a day, and the association was significant $(p=0.004)$. None of the seven women who consumed alcohol had cirrhosis and therefore it was not possible to determine associations between alcohol abuse and cirrhosis in this 
group. Among HBeAg-negative patients with chronic hepatitis who abused alcoholic beverages, $31.4 \%$ were cirrhotic $(16 / 51)$, and the association between alcohol and cirrhosis was significant in this group $(\mathrm{p}=0.001)$. Among HBeAg-positive patients with chronic hepatitis who abused alcoholic beverages, $45 \%$ (9/20) were cirrhotic, although in this group no significant association was observed between alcohol abuse and cirrhosis $(\mathrm{p}=0.197)$.

Sixteen patients (3\%) had HCC, 14 of them with underlying cirrhosis and two without cirrhosis. The mean age of patients with HCC exceeded that of patients without HCC (50.8 versus 37.5 years-old) $(p=0.001)$. No association was detected between the presence of HCC and alcohol consumption ( $\mathrm{p}=1.000)$.

During the study period, six patients were submitted to a liver transplant at HC-FMRP-USP: one due to acute hepatic insufficiency, two due to HCC in a cirrhotic liver and three with decompensation of cirrhosis. Three transplanted patients died. Of the total number of individual studied, 15 died of causes related to HBV infection during the study period.

\section{DISCUSSION}

The Clinics Hospital of the Faculty of Medicine of Ribeirão Preto, University of São Paulo, Ribeirão Preto (HC-FMRP-USP) belongs to the XIII Regional Health Department of the Health Secretariat of the State of São Paulo and is the principal tertiary reference center in the Ribeirão Preto region, which includes 26 municipalities and approximately $1,130,000$ inhabitants $^{19}$. The hepatitis B outpatients clinics of this hospital treats patients with an indication of drug treatment and more severe cases of hepatic disease caused by HBV. This clinic also represents a reference center for cases detected during the donation of blood products at the Ribeirão Preto Blood Center. As observed in the current study, most $(98.5 \%)$ of the care provided by this service involves patients with chronic HBV infection. Cases of symptomatic acute infection are believed to be retained in the primary and secondary health networks.

Analysis of cases of chronic infection revealed a predominance of individuals with the $\mathrm{HBeAg}$-negative/anti-HBeAg-positive serological pattern, with a tendency toward an increase in new $\mathrm{HBeAg}$-negative cases in relation to new $\mathrm{HBeAg}$-positive cases. Studies conducted in France in 1994 and 2003 demonstrated that cases of HBeAg-negative chronic hepatitis also became the most frequent in this region of the European continent over the last decade $^{20,21}$. Cases of HBeAg-negative hepatitis $\mathrm{B}$ also predominate in Greece, with the proportion of Greek patients showing an $\mathrm{HBeAg}$ negative and anti-HBeAg- positive pattern reaching $93.3 \%{ }^{22}$. Studies conducted in Italy, Portugal and Spain have also demonstrated high rates of this serological pattern of chronic $\mathrm{HBV}^{23-25}$. Studies conducted in Brazil have shown differences in the prevalence of HBeAg-negative chronic hepatitis. In northeastern Brazil, in the State of Bahia, Ribeiro et $\mathrm{al}^{16}$ studied 76 individuals with chronic HBV infection and did not identify any patients with $\mathrm{HBeAg-negative} \mathrm{chronic} \mathrm{hepatitis.}$ In contrast, in a study involving $139 \mathrm{HBV}$-infected patients in the City of Campinas, in the southeast region of the State of São Paulo, Tonetto et $\mathrm{al}^{17}$ detected high proportions (70\%) of HBeAg-negative individuals. Similar to that observed in the Campinas study, HBeAgnegative cases predominated in the present study, a fact possibly reflecting greater circulation of $\mathrm{HBV}$ originating from the European continent, particularly the Mediterranean region. In contrast, regarding northeastern Brazil, the data suggest that there is a greater prevalence of $\mathrm{HBV}$ originating from the African continent ${ }^{16,17,26}$.
A previous study conducted in Ribeirão Preto between 1999 and 2002 showed that, of the total number of HBV-infected patients studied, $36 \%$ presented precore and core-promoter mutations: HBV variants that affect the production of the $\mathrm{HBe}$ antigen ${ }^{27}$. In that study, although the number of patients was small $(n=50)$, it was possible to observe that no difference in age was verified between the groups of HBeAg-positive and HBeAg-negative patients ${ }^{27}$. Similarly, in the present study, no difference occurred between the groups of $\mathrm{HBeAg}$-positive and HBeAg-negative patients. These data disagree with results reported in other studies ${ }^{3,17,20,22}$. Since this is a later stage of infection, greater values for age were expected for the group of HBeAg-negative patients ${ }^{3}$. The explanation for these data is not clear, but we suggest that transmission of previously mutant HBV forms, defective for HBeAg synthesis, may have occurred among younger individuals. This hypothesis is supported by the increase in the proportion of $\mathrm{HBeAg}$-negative cases over the last 15 years, a fact that may reflect greater circulation of mutant viruses in our region. However, the fact that HBeAg-negative patients submitted to antiviral treatment were not excluded from this study should be taken into consideration, with the possibility of bias in the data obtained due to the presence of these patients in whom seroconversion of the $\mathrm{HBe}$ antigen was induced by medications.

Regarding the possible mode of transmission, high proportions of sexual risk were verified among the patients with the HBeAg-positive serological pattern, with a predominance of male patients in this group. On the other hand, a high proportion of patients in general with the possibility of vertical/intrafamilial transmission of HBV were also verified, in particular among patients with the HBeAg-negative forms (43.2\%). Studies conducted in Brazil have demonstrated high frequencies of this type of transmission among people living in the same household ${ }^{13-15}$. In a study conducted in Acre, a region of high endemicity for HBV infection in the northern Brazil, Lobato et $\mathrm{al}^{15}$ detected a high frequency of $\mathrm{HBV}$ transmission in the domestic environment among the relatives of HBsAg-positive pregnant women. Motta-Castro et $\mathrm{al}^{14}$ also demonstrated a high frequency of HBV transmission in the family environment, especially among children, in an Afrodescendant community with a high prevalence of HBV infection in the central-western region of Brazil. This last study and others have suggested that dissemination of the virus in the family environment may be more important among individuals of lower socioeconomic level and living in poor hygiene conditions ${ }^{13,14}$. Although the HBeAg-negative serological pattern and the vertical/ intrafamilial form of transmission are known to be more frequent in regions of greater endemicity of infection, studies conducted in Ribeirão Preto on different population groups have suggested a low prevalence of $\mathrm{HBV}$ infection ${ }^{9,10,28}$. However, since in general the patients treated at HC-FMRP-USP are of low socioeconomic level, this result may support the hypothesis raised by Motta-Castro ${ }^{14}$.

In the study model used here, it was not possible to estimate the rates of progression to cirrhosis and to HCC, but it was possible to observe that the proportion of individuals with these complications was similar to that detected in other studies ${ }^{3,20,22}$. Regarding the possible factors related to progression to cirrhosis, this work was in agreement with published data regarding the predominance of these forms of hepatic disease in older individuals ${ }^{1-3}$. Higher rates of cirrhosis were observed in the $\mathrm{HBeAg}$-positive group with chronic hepatitis. Although some studies conducted in European countries have detected greater proportions of cirrhotic individuals in the group of $\mathrm{HBeAg}$-negative patients, there is no consensus regarding the 
influence of the $\mathrm{HBe}$ antigen on the progression to cirrhosis ${ }^{1-3,20,22,29}$ Several studies have highlighted the role of the abusive consumption of alcoholic beverages in the progression of hepatic damage and in the presence of cirrhosis and HCC among patients with chronic hepatitis $B^{2,3,30}$. It should be emphasized that, in the present study, the proportion of abusive consumption of alcoholic beverages by the subjects under study was low, especially among women. This fact agreed with the analyses showing that no association was determined between alcohol consumption and cirrhosis in the female group or in the group with HCC. Similarly, the reduced number of patients with HCC may also have impaired the analyses performed. Among males and among individuals with $\mathrm{HBeAg}$-negative chronic hepatitis, an association between abusive alcohol consumption and cirrhosis was verified, in agreement with published data. However, it should be pointed out that multivariate analyses were not performed and that no information was available regarding other factors that might influence the progression of hepatic disease, such as time of infection, viral load and HBV genotype.

Over the last 15 years, an increase in the proportion of cases of chronic HBV infection presenting the HBeAg-negative form has occurred in the Ribeirão Preto region compared to the HBeAgpositive form. High proportions of HBV-infected individuals with the $\mathrm{HBeAg}$-negative serological pattern were observed, with a higher risk of vertical/intrafamilial transmission. Abusive alcohol consumption was associated with male subjects and with cirrhosis of the liver in this group.

\section{CONFLICT OF INTEREST}

The authors declare that there are no conflicts of interest.

\section{FINANCIAL SUPPORT}

This work was financially supported by the Fundação de Amparo à Pesquisa do Estado de São Paulo (FAPESP).

\section{REFERENCES}

1. Lok ASF, McMahon BJ. Chronic Hepatitis B: Update 2009. Hepatology 2009; 50:661-697.

2. Wright TL. Introduction to chronic hepatitis B infection. Am J Gastroenterol 2006; 101(suppl):1-6.

3. Fattovich G, Bortolotti F, Donato F. Natural history of chronic hepatitis B: special emphasis on disease progression and prognostic factors. J Hepatol 2008 48:335-352.

4. Bosch FX, Ribes J, Cléries R, Díaz M. Epidemiology of hepatocellular carcinoma. Clin Liver Dis 2005; 9:191-211.

5. Silveira TR, Fonseca JC, Rivera L, Fay OH, Tapia R, Santos JI, et al. Hepatitis B seroprevalence in Latin America. Rev Panam Salud Publica 1998; 6: 378-383.

6. Focaccia R, Conceição OJ, Sette Jr H, Sabino E, Bassit L, Nitrini DR, et al. Estimated prevalence of viral hepatitis in the general population of the municipality of São Paulo, measured by a serologic survey of a stratified, randomized and residencebased population. Braz J Infect Dis 1998; 2:269-284.

7. Toledo Jr AC, Greco DB, Felga M, Barreira D, Gadelha M de F, Speranza FA. Seroprevalence of hepatitis B and C in Brazilian army conscripts in 2002. A cross-sectional study. Braz J Infect Dis 2005; 9:374-383.

8. Pereira LMMB, Martelli CMT, Merchán-Hamann E, Montarroyos UR, Braga MC, Lima MLC, et al. Population-based multicentric survey of hepatitis B infection and risk factor differences among three regions in Brazil. Am J Trop Med Hyg 2009; 81:240-247.
9. Miranda LVG, Passos ADC, Figueiredo JFC, Gaspar AMC, Yoshida CFT. Serological markers of hepatitis B in people submitted to blood testing in health care clinics. Rev Saúde Publica 2000; 34:286-291.

10. Valente VB, Covas DT, Passos ADC. Hepatitis B and C serologic markers in blood donors of the Ribeirão Preto Blood Center. Rev Soc Bras Med Trop 2005; 38:488-492.

11. Paraná R, Vitvitski L, Pereira JE. Hepatotropic Viruses in the Brazilian Amazon: A Health Threat. Braz J Infect Dis 2008;12:253-256.

12. Aquino JA, Pegado KA, Barros LP, Machado LFA. Soroprevalência de infecções por vírus da hepatite $\mathrm{B}$ e vírus da hepatite $\mathrm{C}$ em indivíduos do estado do Pará. Rev Soc Bras Med Trop 2008; 41:334-337.

13. Passos ADC, Gomes UA, Figueiredo JFC, Nascimento MMP, Oliveira JM, Gaspar AMC, et al. Influence of migration on prevalence of serological hepatitis B markers in a rural community. Analysis of a prevalence by birth-place. Rev Saude Publica 1993; 27:30-35.

14. Motta-Castro ARC, Yoshida CFT, Lemos ERS, Oliveira JM, Cunha RV, LewisXimenez LL, et al. Seroprevalence of Hepatitis B Virus Infection among an Afrodescendant Community in Brazil. Mem Inst Oswaldo Cruz 2003; 98:13-17.

15. Lobato C, Tavares-Neto J, Rios-Leite M, Trepo C, Vitvitski L, Parvaz P, et al Intrafamilial prevalence of hepatitis B virus in Western Brazilian Amazon region: epidemiologic and biomolecular study. J Gastroenterol Hepatol 2006; 21:863-868.

16. Ribeiro NRC, Campos GS, Ângelo ALD, Braga EL, Santana N, Gomes MMS et al. Distribution of hepatitis B virus genotypes among patients with chronic infection. Liver Int 2006; 26:636-642.

17. Tonetto PA, Gonçales NSL, Fais VC, Vigani AG, Gonçales ESL, Feltrin A, et al Hepatitis B virus: molecular genotypes and $\mathrm{HBeAg}$ serological status among HBVinfected patients in the southeast of Brazil. BMC Infect Dis 2009; 9:149-156.

18. Lok ASF, McMahon BJ. Chronic Hepatitis B: Update 2007. Hepatology 2007; 45:507-539.

19. Secretaria de Estado da Saúde de São Paulo [Internet]. [cited 2010 Apr 10] Available from: http://portal.saude.sp.gov.br/content/geral estrutura regionais_de_saude.mmp/.

20. Zarski JP, Marcellin P, Cohard M, Lutz JM, Bouché C, Raïs A, et al. Comparison of anti-HBe positive and $\mathrm{HBe}$-antigen positive chronic hepatitis $\mathrm{B}$ in France. J Hepatol 1994; 20:636-640.

21. Zarski JP, Marcellin P, Leroy V, Trepo C, Samuel D, Ganne-Carrie N, et al Characteristics of patients with chronic hepatitis B in France: predominant frequency of $\mathrm{HBe}$ antigen negative cases. J Hepatol 2006; 45:355-360.

22. Raptopoulou M, Papatheodoridis G, Antoniou A, Ketikoglou J, Tzourmakliotis D, Vasiliadis T, et al. Epidemiology, course and disease burden of chronic hepatitis $B$ virus infection. HEPNET study for chronic hepatitis B: a multicentre Greek study. J Viral Hepat 2009; 16:195-202.

23. Torre F, Basso M, Giannini EG, Feasi M, Boni S, Grasso A, et al. Clinical and virological survey of patients with hepatitis $\mathrm{b}$ surface antigen in an italian region: clinical considerations and disease burden. J Med Virol 2009; 81:1882-1886.

24. Mota A, Guedes F, Areias J, Pinho L, Cardoso MF. Epidemiological study of genotypes of hepatitis B virus in Northern Portugal. J Med Virol 2009; $81: 1170-1176$

25. Rodriguez-Frias F, Jardi R, Buti M, Schaper M, Hermosilla E, Valdes A, et al. Hepatitis B virus genotypes and G1896A precore mutation in 486 Spanish patients with acute and chronic HBV infection. J Viral Hepat 2006; 13:343-350.

26. Mello FCA, Souto FJD, Nabuco LC, Villela-Nogueira CA, Coelho HSM, Franz HCF, et al. Hepatitis B virus genotypes circulating in Brazil: molecular characterization of genotype F isolates. BMC Microbiol 2007; 7:103-111.

27. Rezende REF, Fonseca BAL, Ramalho LNZ, Zucoloto S, Pinho JRR, Bertolini DA, et al. The precore mutation is associated with severity of liver damage in Brazilian patients with chronic hepatitis B. J Clin Virol 2005; 32:53-59.

28. Passos ADC, Figueiredo JFC, Martinelli ALC, Villanova MG, Nascimento MP, Gaspar AMC, et al. Hepatitis B among female sex workers in Ribeirão Preto São Paulo, Brazil. Rev Bras Epidemiol 2007; 10:517-524.

29. Iloeje UH, Yang HI, Su J, Jen CL, You SL, Chen CJ. Predicting cirrhosis risk based on the level of circulating hepatitis B viral load. Gastroenterology 2006; 130:678-686.

30. Mota A, Guedes F, Areias J, Pinho L, Cardoso MF. Alcohol consumption among patients with hepatitis B infection in northern Portugal considering gender and hepatitis B virus genotype differences. Alcohol 2010; 44:149-156. 